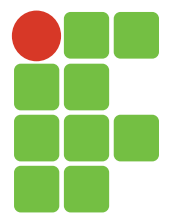

\title{
Nannochloropsis oculata D. microalgae growth in a treated effluent from superintensive shrimp cultivation
}

Bruno Menezes Galindro ${ }^{1}$

Rafael Garcia Lopes ${ }^{2}$

Roberto Bianchini Derner ${ }^{3}$

Sebastião Roberto Soares ${ }^{4}$

\section{Abstract}

The use of microalgae biomass in order to obtain lipids is an important alternative to be studied and it has great potential to be applied in order to produce food and biofuel, for instance. However, there are some processes of its production which need further study, such as the cultivation inputs. A possibility for an alternative raw material is the effluent from superintensive shrimp cultivation with bioflocs (BF). Therefore, the objective of this study was to evaluate the productivity and nutrient removal rate of Nannochloropsis oculata cultivation in three systems: (i) f/2 - produced integrally with chemical fertilizers, (ii) BF - using 100\% of the effluent for superintensive shrimp cultivation with bioflocs and (iii) 50/50 - using 50\% of shrimp cultivation effluents and 50\% from f/2 system. The microalgae presented greater biomass growth and productitvity in BF system but less lipids and esters accumulation. Concerning nutrient removal, $\mathrm{f} / 2$ system showed better performance, which may indicate that the cultivation in BF systems takes longer to reach the stationary growth phase.

Keywords: Microalgae cultivation. Nannochloropsis oculata D. Superintensive shrimp cultivation. Bioflocs.

\section{Introduction}

Due to the increasing demand for alternative power sources, the possibility of using microalgae for this purpose has become frequent in discussions concerning fuel. These microorganisms have been cultivated for commercial application in various areas such as food, chemical and pharmaceutical, and now present themselves as a potential source of raw material for biofuels production, especially biodiesel and bioethanol (ANTONI; ZVERLOV; SCHWARZ, 2007).

According to Clarens et al. (2010), algae have several more favorable characteristics that differ themselves from other biomass sources. Algae tend to produce more biomass than terrestrial plants per unit area. Moreover, unlike these plants, they can be grown in non-arable soils, using fresh or salt water and thus not competing directly with food crops (CHISTI, 2007). Another point is that algae

\footnotetext{
1 Instituto Federal de Santa Catarina, professor. Gaspar, Santa Catarina, Brasil. Universidade Federal de Santa Catarina - doutorando em Engenharia Ambiental. Florianópolis, Santa Catarina, Brasil. bruno.menezes@ifsc.edu.br. (47) 9102-2290. Rua Adriano Kormann, 510, Bela Vista, Gaspar, SC, CEP: 89110-000

2 Universidade Federal de Santa Catarina, técnico do laboratório de microalgas. Florianópolis, Santa Catarina, Brasil. rafael.lopes@ufsc.br. (48) 3721-4106. Campus Universitário, Caixa Postal 476, Trindade, Florianópolis, SC, CEP: 88040-970.

3 Universidade Federal de Santa Catarina, professor. Florianópolis, Santa Catarina, Brasil. roberto.derner@ufsc.br. (48) 3721-4106. Campus Universitário, Caixa Postal 476, Trindade, Florianópolis, SC, CEP: 88040-970.

4 Universidade Federal de Santa Catarina, professor. Florianópolis, Santa Catarina, Brasil. sr.soares@ufsc.br. (48) 3721-6319. Campus Universitário, Caixa Postal 476, Trindade, Florianópolis, SC, CEP: 88040-970.
} 
can be cultivated in systems developed for $\mathrm{CO}_{2}$ absorption and removal of certain pollutants due to its high growth rate and aquatic habitat (POWELL et al., 2008). Among the microalgae species evaluated in order to identify potential biodiesel producers stand the species from Chlorella and Nannochloropsis genus due to its high rate of lipid content (SINGH; GU, 2010).

However, the conventional microalgae cultivation uses chemical fertilizers rich in nitrogen and phosphorus as main sources of nutrients, which can be considered a restriction of this production process due to the large environmental burden generated (LARDON et al., 2009). Clarens et al. (2010) declare that if the fertilizers used in the process were replaced by partially treated effluent, there would be reduction in the environmental impacts of this process.

McGinn et al. (2011) evaluated the integration of microalgae cultivation and industrial wastewater remediation, using it as the culture medium. The paper states that microalgae present great potential for nitrogen, phosphorous and metal pulls removal from industrial and domestic effluents. It is noticed that although there are studies that mention wastewater use as an alternative to reduce the impacts of the microalgae production, technical feasibility on performing cultivation using different culture media still needs further studies.

Among the effluents possibilities to be studied as potential raw materials is the effluent from bioflocs (BFT, Biofloc Technology) production (AVNIMELECH, 2006). This technology is used in superintensive marine shrimp cultivation and is generated from the fertilization of the media with carbon sources and strong oxygenation. In the current situation, at the end of shrimp farming, the effluent is intended for treatment and subsequent release to the environment. Since this organic material has high environmental burden, especially nitrogen and phosphorus, there is a possibility of integrating marine shrimp superintensive cultivation with microalgae growth using effluent in algae cultivation in order to reduce organic matter and increase the production of these organisms. The aim of this study is to evaluate the feasibility of microalgae cultivation in a treated effluent from marine shrimp superintensive cultivation.

\section{Material and methods}

\section{Biological material}

The microalgae species chosen for this study was Nannochloropsis oculata D., which is a unicellular green algae present in marine environment and widely used as food source for shrimp larvae. This microalgal species has great potential for accumulation of lipids and has been studied as a potential source of fatty acids for biodiesel production (CHIU et al., 2009).

\section{Culture media}

The used culture media were: Guillard's f/2 (GUILLARD, 1975) and the liquid fraction from marine shrimp cultivation effluent, pretreated with decantation process and surface filtration. The treatments had the following configuration:

- $f / 2$ : $100 \% \mathrm{f} / 2$ medium. The volume of each experimental unit was composed entirely of Guillard's f/2 medium.

- 50/50 medium: 50\% f/2 and 50\% pretreated effluent. The volume of each experimental unit was composed of equal parts of Guillard's $\mathrm{f} / 2$ medium and the pretreated effluent previously mentioned.

- BF medium: 100\% pretreated effluent from shrimp superintensive cultivation with bioflocs. The volume of each experimental unit was composed entirely by the pretreated effluent previously mentioned. 


\section{Experimental design}

The volume of each experimental unit was stored in fiberglass cylinders, with $120 \mathrm{~L}$ capacity. These units were filled with the corresponding culture medium ( $f / 2,50 / 50$ or BF) and $N$. oculata inoculum was added so that the initial biomass was $0.1 \mathrm{~g} / \mathrm{L}$ in a final $100 \mathrm{~L}$ volume. There were three replicates of each treatment and the experiment cylinders were kept indoors with no temperature and lighting control, with constant aeration generated by an air compressor. The growth experiment was continued until the cultures reach the stationary phase of growth (12 days).

At the end of the experiment, the algae biomass was collected from the cultivation through flocculation method, the lipid fraction was extracted and fatty acid methyl esters (FAME) contents were determined according to Zhu et al. (2002) methodology. Based on these data, the cultivations volumetric productivity was calculated, in grams per liter per day (dry weight) and the productivity per area, in grams per square meter per day (dry weight), considering a relation of 200 liters per square meter of illuminated area (surface).

Representative samples were also collected $(200 \mathrm{ml})$ from each experimental unit at the beginning and at the end of the experiment and the dissolved nutrients in the experimental units were quantified. The physico-chemical parameters analyzed were Biological Oxygen Demand (BOD), nitrogen as ammonia $\left(\mathrm{N}-\mathrm{NH}_{3}\right)$, nitrogen as nitrite $\left(\mathrm{N}-\mathrm{NO}_{2}\right)$, nitrogen as nitrate $\left(\mathrm{N}-\mathrm{NO}_{3}\right)$ and orthophosphate $\left(\mathrm{PO}_{4}\right)$. All procedures follow APHA/AWWA/WEF (2005).

\section{Results and discussion}

\section{Growth and productivity}

After 12 days of cultivation, it was observed that from the initial biomass $(0.1 \mathrm{~g} / \mathrm{L})$, a higher biomass increase was obtained in BF medium, that showed a final concentration of $0.4 \mathrm{~g} / \mathrm{L}$. F/2 and $50 / 50$ media showed less biomass gain, having both $0.33 \mathrm{~g} / \mathrm{L}$ final biomass concentration (Figure 1 ).

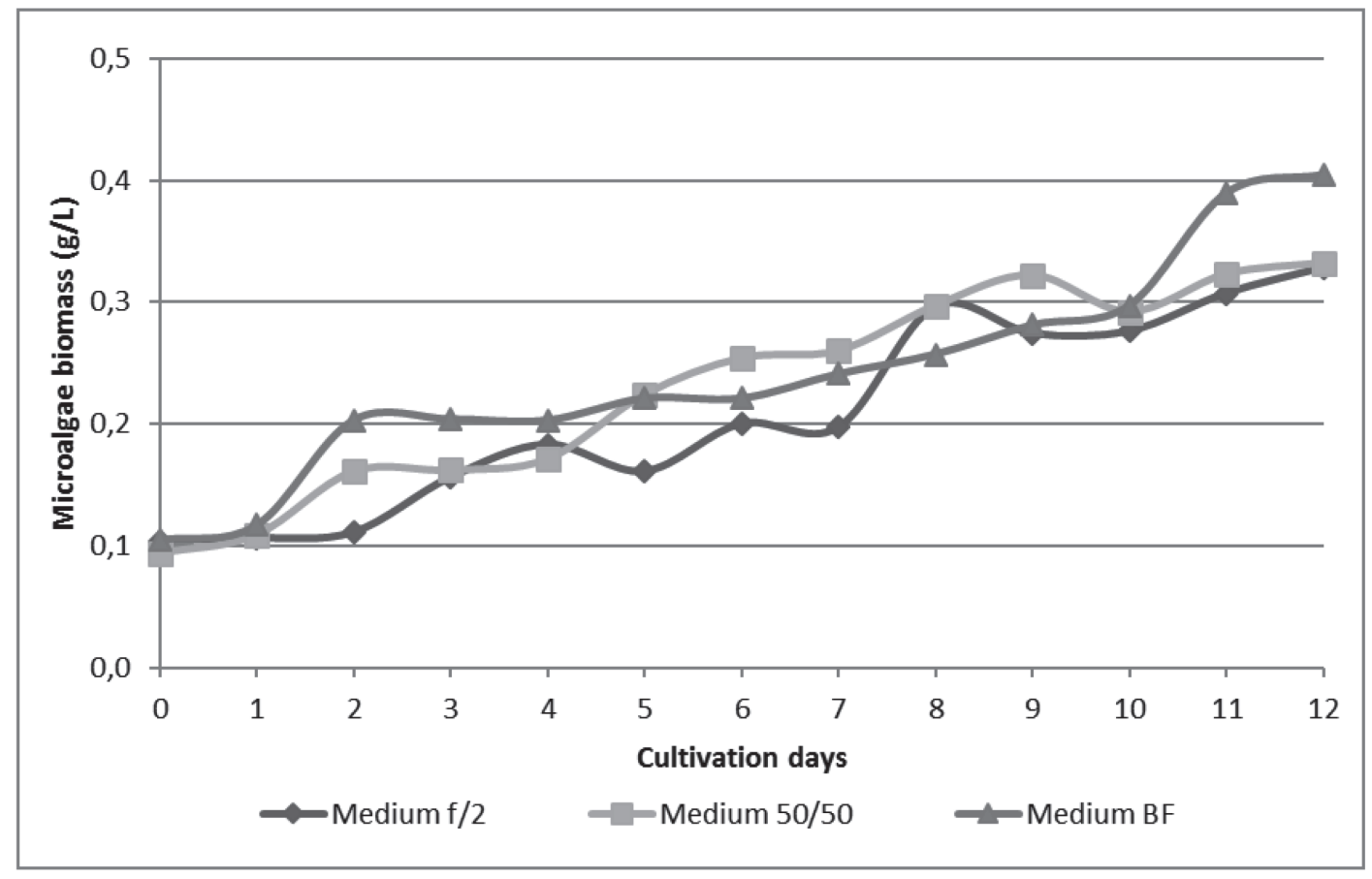

Figure 1. Biomass growth of $N$. oculata using $\mathrm{f} / 2,50 / 50$ and $\mathrm{BF}$ media. 
The cultures performed in this study showed $0.4 \mathrm{~g} / \mathrm{L}$ maximum biomass concentrations when the effluents from superintensive shrimp cultivation were used as medium. However, this value is lower than those described in the literature for $N$. oculata, that range from 0.5 to $1.0 \mathrm{~g} / \mathrm{L}$ (Richmond, 2004).

Table 1 shows that BF medium represented the highest average volumetric productivity $(0.03$ $\mathrm{g} / \mathrm{L} / \mathrm{d})$ and higher average productivity per area $\left(5.0 \mathrm{~g} / \mathrm{m}^{2} / \mathrm{d}\right)$. On the other hand, $\mathrm{f} / 2$ and 50/50 media showed $33.3 \%$ lower average volumetric productivity $(0.02 \mathrm{~g} / \mathrm{L} / \mathrm{d})$ and $24.4 \%$ lower average productivity per area $\left(3.83 \mathrm{~g} / \mathrm{m}^{2} / \mathrm{d}\right)$.

Table 1. Average productivity of $N$. oculata in different culture media.

\begin{tabular}{|c|c|c|c|c|c|c|c|}
\hline $\begin{array}{l}\text { Culture } \\
\text { media }\end{array}$ & $\mathbf{B i}^{1}(g / L)$ & $\begin{array}{c}\operatorname{MaxB}^{2} \\
(\mathrm{~g} / \mathrm{L})\end{array}$ & $\mathrm{AcB}^{3}(\mathrm{~g} / \mathrm{L})$ & $\begin{array}{l}\text { Time }^{4} \\
\text { (days) }\end{array}$ & $\begin{array}{c}\text { Vol } \\
\text { prod }^{5} \\
\text { (g/L/d) }\end{array}$ & $\begin{array}{c}\text { Prod } \\
\text { area }^{6} \\
\left(\mathrm{~g} / \mathrm{m}^{2} / \mathrm{d}\right)\end{array}$ & $\begin{array}{c}\text { Prod } \\
\text { area }^{7} \\
(\mathrm{t} / \mathrm{ha} / \mathrm{y})\end{array}$ \\
\hline $\mathrm{f} / 2$ & 0.10 & 0.33 & 0.23 & 12 & 0.02 & 3.83 & 13.99 \\
\hline $50 / 50$ & 0.10 & 0.33 & 0.23 & 12 & 0.02 & 3.83 & 13.99 \\
\hline BF & 0.10 & 0.40 & 0.30 & 12 & 0.03 & 5.00 & 18.25 \\
\hline
\end{tabular}

1- Biomass; 2- Maximum biomass achieved; 3- Accumulated biomass ( $\mathrm{MaxB}$ - $\mathrm{Bi}$ ); 4- Time in which MaxB was achieved; 5- Volumetric Productivity (AcB/Time); 6- Productivity per area $\mathrm{m}^{2} /$ day (Vol prod x $\left.200=200 \mathrm{~L} / \mathrm{m}^{2}\right)$; 7- Productivity per area in hectares/year (Prod area in $\mathrm{m}^{2} /$ day $\times 365$ days).

Source: created by the authors

It can be noticed that all the treatments from this study showed low volumetric productivity as well as low productivity per area. While the maximum volumetric productivity obtained in this study was $0.03 \mathrm{~g} / \mathrm{L} / \mathrm{d}$, there are productivity records ranging from 0.025 to $0.125 \mathrm{~g} / \mathrm{L} / \mathrm{d}$ (FULKS; MAIN, 1991). In a similar situation to this study, cultivating the same microalgae species in fiberglass cylinders, James and Al-Khars (1990) obtained average $0.05 \mathrm{~g} / \mathrm{L} / \mathrm{d}$ volumetric productivity.

These findings are associated with the fact that in the present study artificial lighting and temperature control were not used. Therefore, the algae were submitted to natural lighting photoperiod and to changes in ambient temperature, which may have reduced growth, biomass production and therefore productivity.

Comparing the present study with others that also use natural light, it still shows lower productivity per area. In these studies, productivity greater than $10 \mathrm{~g} / \mathrm{m}^{2} / \mathrm{d}$ (RICHMOND, 2004) was observed. However, it is important to emphasize that James and Al-Khars (1990), Fulks and Main (1991) and Richmond (2004) studies were developed in suitable structures for microalgae cultivation, both open ponds and photobioreactors, are designed in order to increase the crops illuminated surface, optimizing the photosynthesis and growth rate. The fiberglass cylinders used in this study are more suitable for crops that use artificial lighting.

\section{Total lipids and FAME}

The analysis of total lipid content in biomass presented similar average values for the three culture media. 50/50 medium showed the highest average lipid accumulation, $15.36 \%$; the f/2 medium obtained $14.93 \%$ and BF presented $12.99 \%$ lipid content in biomass.

Several conditions are important to assess whether a raw material can be used for the biodiesel production. For microalgae, we evaluate the yield of direct transesterification, as FAME content in biomass. The 50/50 medium samples presented the highest esters levels (94.6 milligrams of esters 
per gram of biomass). The $\mathrm{f} / 2$ medium showed $90 \mathrm{mg}$ of esters per gram of biomass. In BF culture medium, the lower accumulation of this material was found, 88.8 milligrams of esters per gram of biomass.

Considering the amount of esters relatively to the total lipid and the yield of biomass per area, it is possible to observe that although there is a minor lipids and esters microalgae accumulation in BF medium, the esters productivity per area is still higher ( $1.62 \mathrm{t} / \mathrm{ha} / \mathrm{year}$ ) than the values found in $\mathrm{f} / 2$ media ( $1.26 \mathrm{t} / \mathrm{ha} /$ year) and 50/50 (1.32 t/ha/year). This is directly related to the increased productivity of biomass per area located between BF, as shown in Table 2.

Table 2. Productivity per area related to total lipids and FAME.

\begin{tabular}{cccccc}
\hline $\begin{array}{c}\text { Culture } \\
\text { Media }\end{array}$ & $\begin{array}{c}\text { Prod } \\
\text { Area (t/ha/y) }\end{array}$ & $\begin{array}{c}\text { Total } \\
\text { Lipids } \\
\text { (\% average })\end{array}$ & $\begin{array}{c}\text { FAME } \\
\text { (\% average) }\end{array}$ & $\begin{array}{c}\text { Lipid Prod per } \\
\text { Área (t/ha/y) }\end{array}$ & $\begin{array}{c}\text { Ester Prod } \\
\text { Per Area (t/ } \\
\text { ha/y) }\end{array}$ \\
\hline $\mathbf{f} / \mathbf{2}$ & 13.99 & 14.93 & 9.00 & 2.09 & 1.26 \\
$\mathbf{5 0 / 5 0}$ & 13.99 & 15.36 & 9.46 & 2.15 & 1.32 \\
BF & 18.25 & 12.99 & 8.88 & 2.37 & 1.62 \\
\hline
\end{tabular}

Source: created by the authors

Regarding lipid and FAME in biomass, the maximum value obtained in this study was $15.36 \%$ in 50/50 culture medium. Chisti (2007) states that, for Nannochloropsis sp., the percentage of accumulated lipid in biomass can vary from 31 to $68 \%$, depending on cultivation type used. It is perceived that improvements are needed in cultures concerning productivity per area, such as adjustment of culture structures, so that they become feasible for commercial production of biodiesel.

\section{Nutrient consumption.}

After 12 days, significant reduction in nitrate $\left(\mathrm{N}-\mathrm{NO}_{3}\right)$ and orthophosphate $\left(\mathrm{PO}_{4}\right)$ of the culture media in the three treatments was observed. BOD rates showed little variation, with an increase in $50 / 50$ medium and decrease in $\mathrm{f} / 2$ and $\mathrm{BF}$ media. The concentrations of nitrite $\left(\mathrm{N}-\mathrm{NO}_{2}\right)$ presented total consumption in $\mathrm{f} / 2$ and $\mathrm{BF}$; in some samples, they were not detected.

Regarding ammonia $\left(\mathrm{N}-\mathrm{NH}_{3}\right)$ concentration in the cultures, there was a reduction of its concentration in the three crops: $26 \%$ in $\mathrm{f} / 2$ (from 1.6 to $1.2 \mathrm{mg} / \mathrm{l}$ ), $22.7 \%$ in 50/50 (from 1.9 to 1.5 $\mathrm{mg} / \mathrm{l}$ ) and $35.6 \% \mathrm{BF}$ (from 2.3 to $1.5 \mathrm{mg} / \mathrm{l}$ ). The $\mathrm{f} / 2$ medium presented the lowest concentrations, both initial and final, for this parameter.

BOD was reduced to $58 \%$ in $\mathrm{f} / 2$ culture media (from 7.7 to $3.2 \mathrm{mg} / \mathrm{l}$ ) and $43 \%$ in $\mathrm{BF}$ (from 7.1 to $4.0 \mathrm{mg} / \mathrm{l}$ ). However, the $50 / 50$ medium had an increase of $26 \%$ in BOD (from 7.4 to $10.0 \mathrm{mg} / \mathrm{l}$ ) after algae cultivation (Figure 2). 


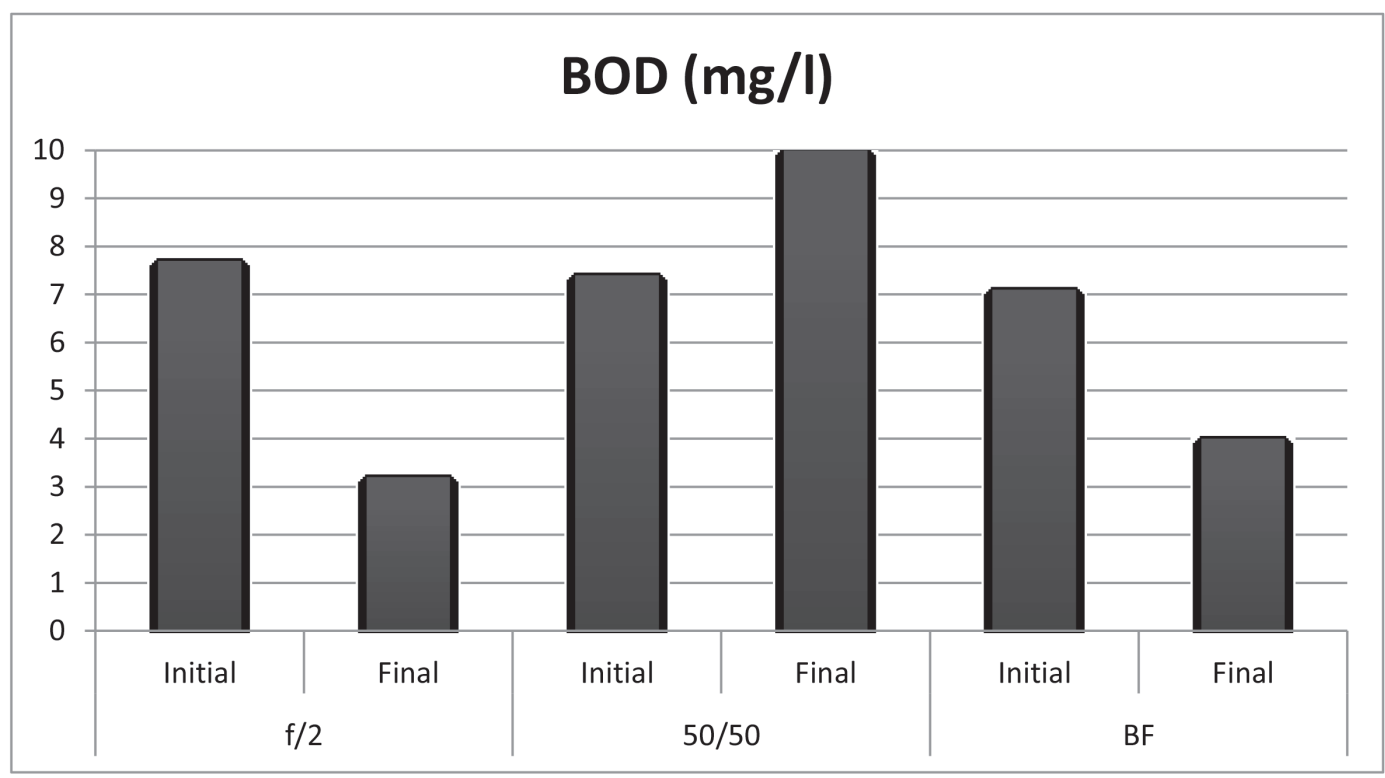

Figure 2. Biological Oxygen Demand (BOD) of cultivation systems ( $\mathrm{mg} / \mathrm{l})$.

Source: created by the authors

Regarding nitrate concentration, it is possible to realize that there was nearly complete consumption of nitrate dissolved in $\mathrm{f} / 2$ medium (from 12.5 to $0.01 \mathrm{mg} / \mathrm{l}$ ). Moreover, 50/50 and BF media showed higher final values of nutrient concentration, wich means less nitrate consumption (53.7 and $22.7 \%$, respectively). Figure 3 shows that the highest concentrations were obtained in $\mathrm{BF}$ system (15.32 mg/l initial and $11.9 \mathrm{mg} / \mathrm{l}$ final) and 50/50 system presented $11.1 \mathrm{mg} / \mathrm{l}$ inital and 5.2 $\mathrm{mg} / \mathrm{l}$ final concentrations.

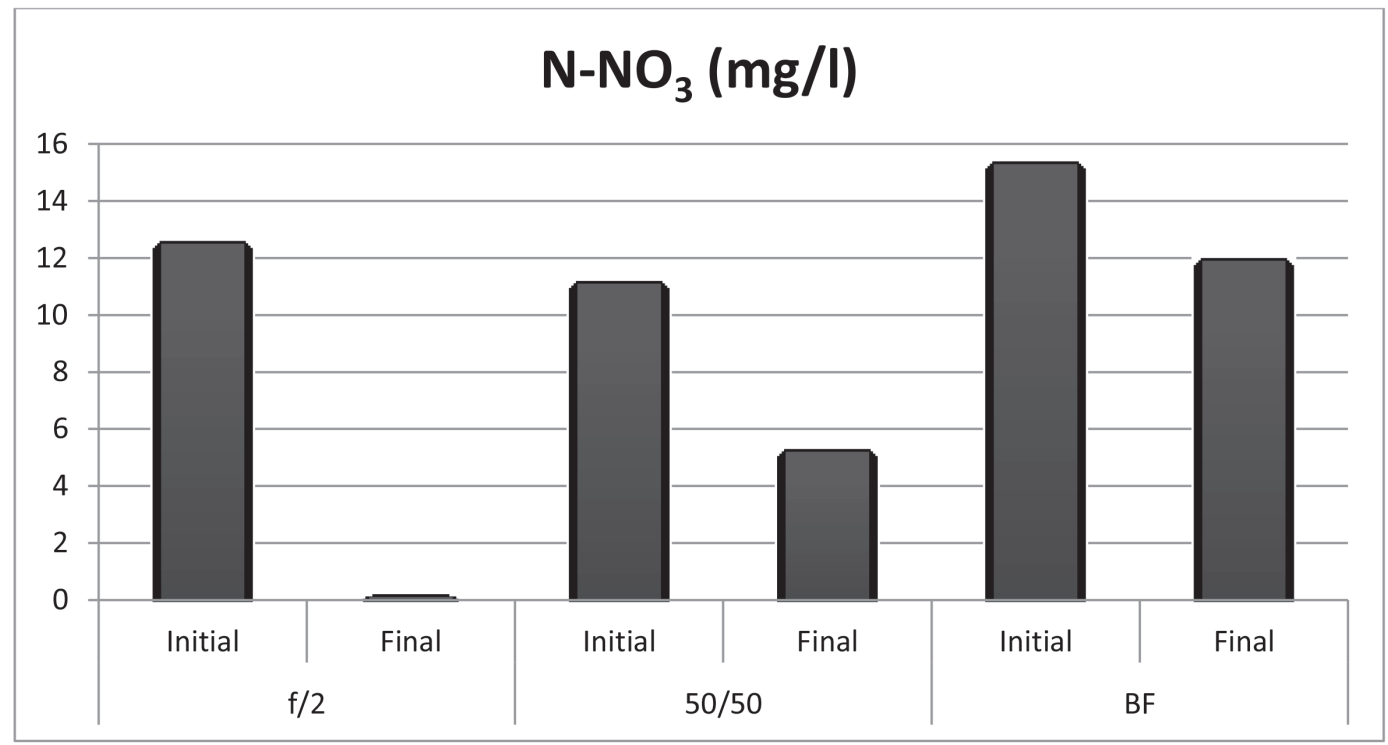

Figure 3. Nitrogen as nitrate $\left(\mathrm{N}-\mathrm{NO}_{3}\right)$ of cultivation systems $(\mathrm{mg} / \mathrm{l})$. Source: created by the authors

The concentrations of orthophosphate presented the most significant reduction in all three culture media, almost being completely consumed in all of them (Figure 4). The reduction in concentration was $99.2 \%$ in f/2 (from 12.5 to $0.1 \mathrm{mg} / \mathrm{l}$ ), $91.7 \%$ in $50 / 50$ (from 14.5 to $1.2 \mathrm{mg} / \mathrm{l}$ ) and $94 \%$ in BF (from 16.1 to $1.0 \mathrm{mg} / \mathrm{l})$. 


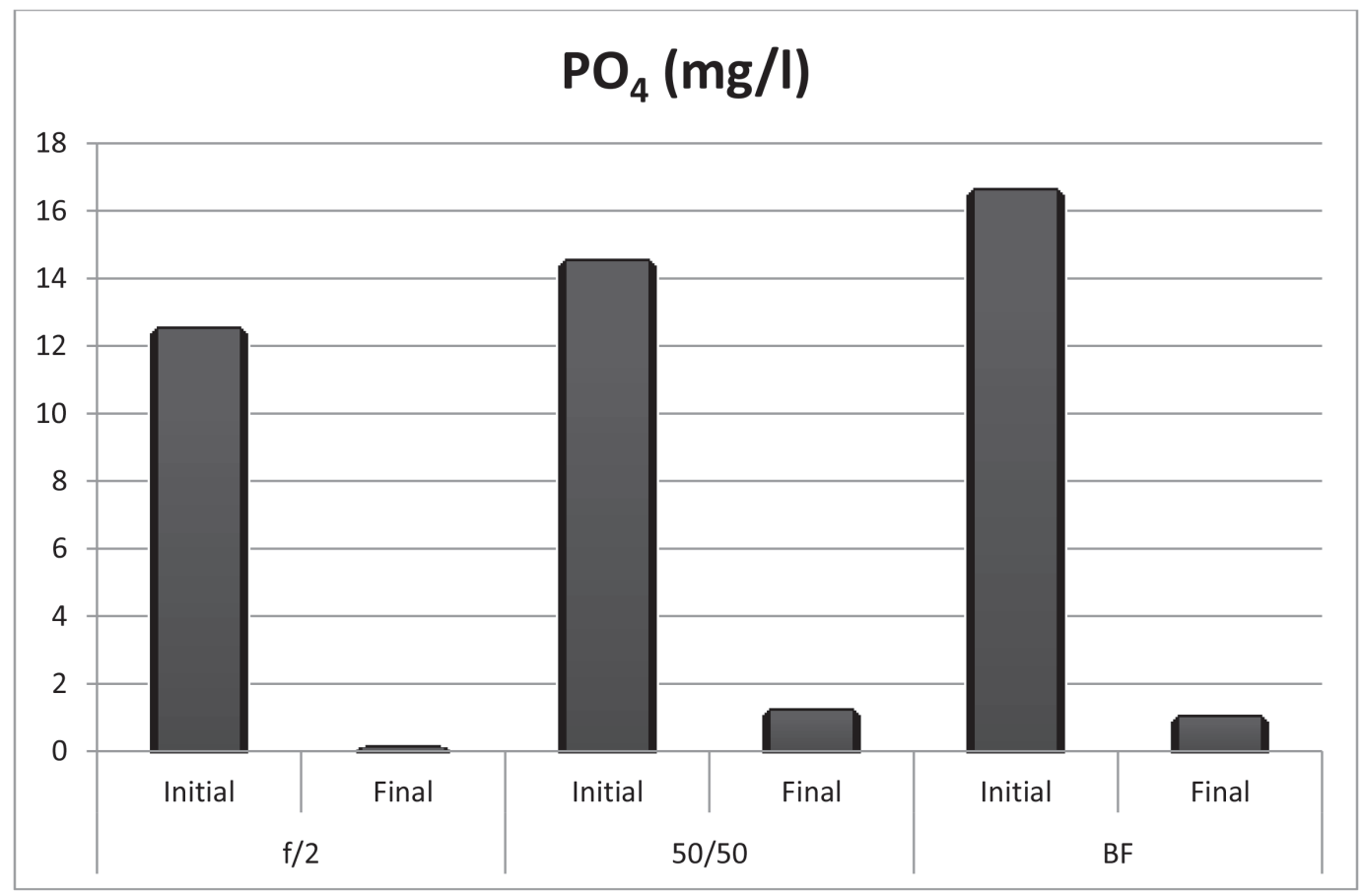

Figure 4. Orthophosphate $\left(\mathrm{PO}_{4}\right)$ of cultivation systems $(\mathrm{mg} / \mathrm{l})$.

Source: created by the authors

Observing the growth curves on Figure 1, it is possible to infer that, apparently, 50/50 and BF microalgae crops were still in the exponential growth phase when the experiment was finished. This can be further corroborated by the observation of chemical parameters, which can show that there was nutrients availability in these media at the end of the experiment, especially nitrate and phosphate. If the growth of microalgae is extended for a longer time, it is possible that higher productivity could be generated in these treatments. As for $\mathrm{f} / 2$ medium, we can infer that its productivity was lower than other crops because all the available phosphate was assimilated and, therefore, this nutrient may have limited the production of biomass.

Regarding to nutrient removal from the culture media, the microalgae cultivated in $f / 2$ media presented the highest removal efficiency for all the analysed parameters, except ammonia, in which $\mathrm{f} / 2$ was the most efficient one. We also observed that microalgae cultivation may represent a potential nutrient remover from superintensive shrimp cultivation with bioflocs effluent, with a removal rate varying from 25 to $50 \%$, depending on the analysed parameter.

Chisti (2007) states that the phosphate availability in the medium is one of the main limiting growth fator for microalgae. In the present study, the phosphate was totally consumed in all the cultures, but the presence of a small amount of phosphate in 50/50 and BF may indicate that the algae have not reached the stationary growth phase yet.

For all other parameters, McGinn et al. (2011) state that the removal of the dissolved nutrients in microalgae cultivation using wastewater is approximately $80 \%$. This study obtained similar values removal in $\mathrm{f} / 2$ and less on 50/50 and BF. However, it is important to point out that the conditions in which treatments of this study were submitted were different from those described in the literature, especially regarding to lighting. This may have contributed to reducing the growth of microalgae and the removal of dissolved nutrients in 50/50 and BF culture medium. 


\section{Conclusions}

Through this study, it was established that $N$ oculata microalgae species have potential to grow in culture media that use the effluent of superintensive shrimp farming. However, the low productivity in relation to lipid content indicates that this form of cultivation is probably not feasible on a large-scale production. The results also seem to indicate that microalgae can be used to treat effluents from superintensive shrimp farming.

Regarding the gain of biomass, algae showed superior growth in BF system compared to the traditional $f / 2$ medium growth, which uses chemical fertilizers. The option to combine these two culture media, using $50 \%$ of each in the final composition, showed similar growth and biomass gain to BF system.

The results indicate that the concentration of phosphate, nitrate, nitrite, and ammonia and BOD have been reduced in the environment after using effluent as a growth medium for microalgae. Further studies are needed to assess other physical and chemical effluent parameters and the removal of nutrients through cultivation.

\section{Acknowledgments}

This research Project would not have been possible without the support of Universidade Federal de Santa Catarina, especially the researchers from Laboratório de Cultivo de Algas and Laboratório de Camarões Marinhos. Special thanks to Carlos Manoel do Espírito Santo, Caio Magnotti and Rafael Arantes.

\section{Crescimento da microalga Nannochloropsis oculata D. em um efluente oriundo de cultivo superintensivo de camarões}

\section{Resumo}

A utilização de microalgas para a obtenção de lipídios é uma alternativa importante a ser estudada e tem demonstrado grande potencial de aplicação para a produção de alimentos e biocombustíveis, por exemplo. No entanto, há poucos estudos relacionados ao seu processo de produção, especialmente quando se refere a insumos para cultivo. Nesse sentido, uma alternativa viável para o cultivo das algas pode ser a utilização de efluentes oriundos de tanques de cultivo superintensivo de camarões. 0 objetivo deste estudo foi avaliar a produtividade e a taxa de remoção de nutrientes do cultivo da microalga Nannochloropsis oculata em três sistemas: (i) f/2 - utilizando apenas fertilizantes químicos, (ii) BF - utilizando $100 \%$ do efluente do cultivo superintensivo de camarões com bioflocos e (iii) $50 / 50$ - utilizando $50 \%$ de efluentes de cultivo de camarões e $50 \%$ de meio $\mathrm{f} / 2$. A microalga apresentou maior crescimento em biomassa e produtividade no sistema BF, porém, menor acumulação de lipídios e ésteres. No que se refere à remoção de nutrientes, o sistema f/2 apresentou melhor desempenho, o que pode indicar que o cultivo em meio BF leva mais tempo para atingir a fase estacionária de crescimento.

Palavras-chave: Cultivo de microalgas. Nannochloropsis oculata. Cultivo superintensivo de camarões. Bioflocos. 


\section{References}

ANTONI, D.; ZVERLOV, V. V.; SCHWARZ, W. H. Biofuels from microbes. Applied Microbiology and Biotechnology, v. 77, p. 23-35. 2007.

APHA/AWWA/WEF. Standard methods for the examination of water and wastewater. 21 ed. Washington, DC: APHA, 2005.

AVNIMELECH, Y. Bio-filters: the need for a new comprehensive approach. Aquacultural Engineering. v. 34, p. 172-178. 2006.

CHIU, S.Y.; KAO, C.Y.; TSAI, M.T.; ONG, S.C.; CHEN, C.H.; LIN, C.S. Lipid accumulation and $\mathrm{CO}_{2}$ utilization of Nannochloropsis oculata in response to $\mathrm{CO}_{2}$ aeration. Bioresource Technology. v. 100, p. 833-840. 2009.

CHISTI, Y. Biodiesel from microalgae. Biotechnology Advances. v. 25, p. 294-306. 2007.

ClARENS, A. F.; RESSURRECCION, E. P; WHITE, M. A.; COLOSI, L., M. Environmental Life Cycle Comparison of Algae to Other Bioenergy Feedstocks. Environmental Science and Technology. v. 44, p. 1813-1819. 2010.

FULKS, W.; MAIN, K. L. US-ASIA Workshop 1991 Proceedings. Honolulu: The Oceanic Institute. 1991. GUILLARD, R. R. L. 1975. Culture of phytoplankton for feeding marine invertebrates. In: SMITH, W. L., CHARLEY, M. H. Culture of Marine Invertebrate Animals. New York: Plenum, 1975. p. 29-60.

JAMES, C. M.; AL-KHARS, A. M. An intensive continuous culture system using tubular photobioreactors for producing microalgae. Aquaculture. v. 87, p. 381-393. 1990.

LARDON, L.; HÉLIAS, A.; SIALVE, B.; STEYER, J.; BERNARD, O. Life-cycle assessment of biodiesel production from microalgae. Environmental Science and Technology. v. 17, p. 6475-6481. 2009.

MCGINN, P. J.; DICKINSON, K. E.; BHATTI, S.; FRIGON, J.; GUIOT, S. R.; O'LEARY, S. J. B. Integration of microalgae cultivation with industrial waste remediation for biofuel and bioenergy production: opportunities and limitations. Photosynthesis Research. v. 109, p. 231-247. 2011.

POWELL, N.; SHILTON, A. N.; PRATT, S.; CHISTI, Y. Factors influencing luxury uptake of phosphorus by microalgae in waste stabilization ponds. Environmental Science and Technology. v. 42, p. 5958-5962. 2008.

RICHMOND, A. CRC Handbook of Microalgal Mass Culture. Boca Raton : CRC, 2004.

SINGH, J.; GU, S. Commercialization potential of microalgae for biofuels production. Renewable and Sustainable Energy Reviews. v. 14, p. 2596-2610. 2010.

ZHU, M.; ZHOU, P. P.; YU, L. J. Extraction of lipids from Mortierella alpina and enrichment of arachidonic acid from the fungal lipids. Bioresource Technology. v. 84, p. 93-95. 2002.

\section{Histórico editorial}

Submetido em: 04/10/2014

Aceito em: 12/02/2015 


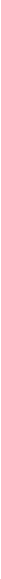

